\title{
Government Office: Effect of Work Motivation, Work Satisfaction, and Organizational Climate on Employee Performance
}

\author{
Silvia Veronika ${ }^{1} \quad$ Anwar Sanusi $^{2} \quad$ Harianto Respati $^{2}$ (Corresponding Author) \\ 1.Student at Magister Management Program, University of Merdeka Malang, Indonesia \\ 2.Faculty of Economics and Business, University of Merdeka Malang, Indonesia \\ Corresponding Author email: patidarma@yahoo.com
}

\begin{abstract}
The purpose of this study is to examine which of the work motivation, work satisfaction and organizational climate dominant influence on the performance of government employees. The uniqueness of this research is the results of the study are presented to improve office management for organizational sustainability. This research has been conducted at the Investment and Integrated Services Office of Pasuruan Regency. The total population of the study was 36 units of analysis, using the census method. The design of this study is quantitative. Analysis techniques have used multiple linear regression. The results showed that the work motivation of employees based on collaboration with colleagues can improve the performance of employees' hard skills, namely the ability gained from work experience. This aspect of collaboration is a suggestion for the organization under study and for future researchers
\end{abstract}

Keywords: work motivation, work satisfaction, organizational climate, employee performance, pasuruan

DOI: $10.7176 / \mathrm{IKM} / 9-11-04$

Publication date: December $31^{\text {st }} 2019$

\section{INTRODUCTION}

Performance is the result or overall level of success of a person during a certain period in carrying out tasks, such as work standards, targets or targets or criteria determined by the organization (Rivai and Basri, 2005). Some experts agree that work requires motivation, namely to get certain economic values such as salary, compensation, bonus premiums, vehicles, and incentives. There also requires motivation to obtain certain social values. Social values or immaterial values such as appreciation, respect, admiration of friends, social status, prestige, and self-actualization. Not always the motivation is tangible money. Pride in his own work, great interest in work is a strong incentive to realize a job. Aspects of the work environment and motivation are one of the main keys in achieving the common goals that people expect

In addition, job satisfaction is no less important in achieving employee performance. According to Luthans (2012), job satisfaction was an emotion resulting from a response to a work situation, so job satisfaction cannot be seen but can be felt and shown in attitudes such as loyalty to the organization, working optimally, and complying with organizational regulations. The human resource management department always monitors employee job satisfaction because it affects absenteeism, labor turnover, and other employee complaints. Job satisfaction becomes feedback that can affect employee performance in an agency. The impact of job satisfaction tends to focus on employee performance, the level of attendance, and the level of employee turnover. Organizations with more satisfied employees tend to be more performers and disciplined to attend work and lower turnover compared to organizations that have less satisfied employees (Robbins, 2013). Dimyati (2011) and Sukarman (2014) research have proven that job satisfaction influences employee performance. Job satisfaction is a personal thing, meaning that it can be felt by the individual concerned. Therefore, job satisfaction needs to be investigated in this study.

Employee performance is created from a conducive organizational climate. To improve employee performance indicators can be done through improving the organizational climate. Organizational climate according to Stringer (2006) is an environmental condition that determines the desire to perform. Rahmawati and Supartha's research results (2015), Yusuf (2017), Pasaribu and Indrawati (2016), and Dewi (2017) prove that organizational climate influences employee performance.

Vision and Mission of the Department of Investment and Integrated Services of Pasuruan Regency, namely increasing licensing services consisting of the satisfaction of the applicant, increasing the value of an investment in quality and quantity, as well as increasing real regional income. The main performance indicator of the Office of Investment and Integrated Services of Pasuruan Regency is the increase in revenue from the region through revenue from retribution during the span of one fiscal year. The performance of the office in 2015 to 2017 has increased compared to the achievements in previous years 
Figure 1. Percentage diagram of performance achievement in 2015 - 2017

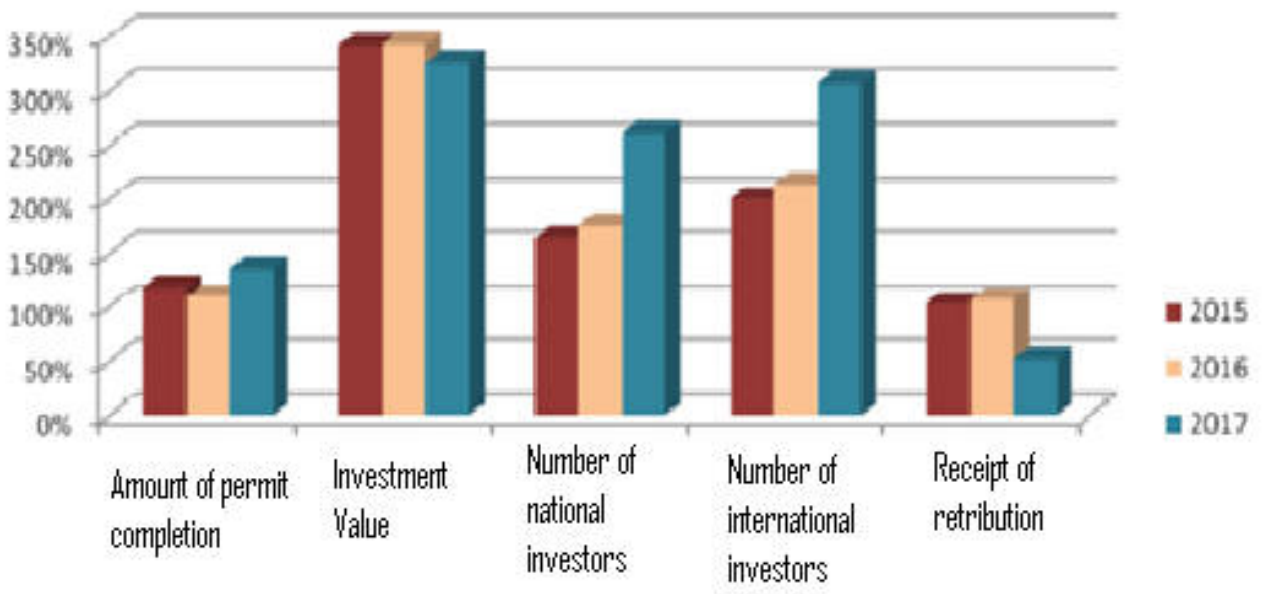

Source: Investment and Integrated Services Office of Pasuruan Regency (2018)

Performance achievement in 2017 was supported by several efforts made by the Pasuruan Regency Investment and Integrated Services team, including: implementing Service Quality Standards; improve the quality of licensing and non-licensing services; optimize the promotion of investment potential in Pasuruan Regency; improve the quality of human resources apparatus; improve coordination with the business world; synchronize the implementation of investment through monitoring, coaching and supervision; improve coordination with other Technical Offices related to licensing and non-licensing services, as well as optimize information systems at the Investment and Integrated Services Office of Pasuruan Regency.

It is suspected that work motivation, job satisfaction, and organizational climate are the deciding factors in improving performance in the office. There is no research in this office that explains the factors of work motivation, job satisfaction and organizational climate-related to employee performance. So it is necessary to explain work motivation, job satisfaction and organizational climate which is dominant in influencing employee performance. This research is useful for the Investment and Integrated Services Office of Pasuruan Regency for managerial decision making.

\section{LITERATURE REVIEW}

\section{Employee Performance}

The performance of government agencies is a picture of the level of achievement of goals or objectives. The term performance comes from the word job performance or actual performance which means work performance or achievement achieved by someone. According to Hasibuan (2011) performance is a result of work achieved by employees when carrying out tasks based on skills, experience, and sincerity in a certain period.

Performance is a result obtained from work as a contribution to the agency, employee performance is measured by two indicators namely Hard skills and Soft skills.

\section{Work motivation}

According to Hasibuan (2011) is a driving force that creates a person's work passion to work effectively and organized with all the effort for the goals of the organization. Furthermore Motivation according to Robbins (2013) is the willingness of individuals to carry out and realize organizational goals. Winardi (2011) has explained the word motivation comes from the Latin "movere" which means to move. Human behavior moves to do something on the basis of encouragement called motivation. Many psychologists use different terms to refer to something that causes this behavior. There are those who call it motivation. Needs, urges, drives, wishes.

Work Motivation is the employee's motivation to do something full of awareness for the achievement of organizational goals. The indicators used in this study to measure work motivation are the need for power, the need for achievement and the need for affiliation

\section{Job satisfaction}

Job satisfaction according to Luthans (2012) is an emotional response based on the perceived work situation. Kreitner and Kinicki (2010) have explained that job satisfaction is "the effectiveness or emotional response to various aspects of work". Luthans (2012) describes "job satisfaction is the employee's feelings either pleasant or unpleasant for the workload". According to Robbins (2013) job satisfaction is "a person's attitude from the results of comparing between sacrifice and appreciation for work.

Job satisfaction is everything that is around the place of work both physical job satisfaction and nonphysical job satisfaction. Indicators of job satisfaction in this study consisted of two namely extrinsic satisfaction and intrinsic satisfaction. 


\section{Organizational Climate}

Organizational climate according to Simamora (2010) is an internal environmental condition or organizational psychology. Organizational climate is closely related to the practice of interaction between human resources and the environment of the organization. Each organization has a different organizational climate. According to Wirawan (2010), organizational climate is the perception of organizational members both individuals or groups that are constantly in contact with the organization and follow what happens to the company's internal and external environment.

Organizational climate is a situation of pressure experienced by someone associated with the work process in the face of enormous work demands, quality and relationships between peers and with superiors. The organizational climate in this study was measured by structure, responsibility, appreciation, support, and commitment.

\section{METHODOLOGY}

\section{Population and Sampling Techniques}

The population of this study is all employees who work in the Department of Investment and Integrated Services of Pasuruan Regency are 36 people. The number of samples in this study was 36 people, so the sampling technique was a census, where all members of the population were sampled.

\section{Data analysis technique}

The data analysis method in this study was carried out with the following techniques:

1. Descriptive Analysis

This analysis is to explain the picture in a measured condition. After the data has been collected, tabulation is performed to further analyze the description using the mean statistical tool.

The technique used to describe field data descriptively by interpreting the results of data processing through tabulation.

2. Multiple Linear Regression Analysis

Multiple Linear Regression Analysis is used to determine the effect of Work Motivation, Job Satisfaction and Organizational Climate on Employee Performance. This regression analysis is assisted by the SPSS program. The equation of the regression equation model is: $Y=a+b_{1} X_{1}+b_{2} X_{2}+b_{3} X_{3}+e$

Note;

$$
\begin{array}{ll}
\mathrm{Y} & =\text { Employee Performance } \\
\mathrm{a} & =\text { constant number } \\
\mathrm{b}_{1 . .} \mathrm{b}_{3} & =\text { regression coefficient } \\
\mathrm{X}_{1} & =\text { Work Motivation } \\
\mathrm{X}_{2} & =\text { Job Satisfaction } \\
\mathrm{X}_{3} & =\text { Organizational Climate } \\
\mathrm{e} & =\text { confounding variable }
\end{array}
$$

\begin{tabular}{|c|c|c|c|c|}
\hline Variables & Regression Coefficient & $t_{\text {statistic }}$ & p. & result \\
\hline Work motivation $\left(\mathrm{X}_{1}\right)$ & 0,482 & 4,916 & 0,000 & Significant \\
\hline Job satisfaction $\left(\mathrm{X}_{2}\right)$ & 0,342 & 3,534 & 0,001 & Significant \\
\hline Organizational climate $\left(\mathrm{X}_{3}\right)$ & 0,192 & 2,357 & 0,025 & Significant \\
\hline Constanta & $-0,021$ & & & \\
\hline $\mathrm{R}$ & 0,928 & & & \\
\hline Adjusted $R$ square & 0,848 & & & \\
\hline $\mathrm{F}$-statistic & 65,951 & & & \\
\hline Probability of F & 0,000 & & & \\
\hline \multicolumn{5}{|c|}{ Dependent variable $=$ Employee Performance $(Y)$} \\
\hline $\begin{array}{l}\mathrm{F} \mathrm{t}_{\text {able }}=2,90 \\
\mathrm{t}_{\text {table }}=2,042\end{array}$ & & & & \\
\hline
\end{tabular}

\section{RESULTS AND DISCUSSION}

\section{Multiple Regression Analysis}

The results of data processing using SPSS for windows computer program help obtained the results of the analysis as in Table 1 below

Table 1. Recapitulation of multiple linear regression analysis results.

In accordance with the recapitulation results in Table 1, the multiple regression equation is obtained as follows: $\mathrm{Y}=-0,021+0,482 \mathrm{X}_{1}+0,342 \mathrm{X}_{2}+0,192 \mathrm{X}_{3}$

The equation model has good accuracy to be accepted as an analysis tool. It is proven that the value of $\mathrm{F}$ statistic $(65,951)>$ F table $(2.90)$ with an error accuracy level of $p=0,000$ does not exceed the error rate $(0.05)$.

This equation explains that the negative number of 0.021 means that employee performance has decreased 
due to factors other than work motivation, job satisfaction, and organizational culture. The result of $\mathrm{R}=0.928$ explains the high level of closeness between employee performance and three variables (namely: work motivation, job satisfaction, and organizational culture). The contribution of these three variables at 84.8 is explained by the value of the Adjusted $\mathrm{R}$ square $(0.848)$. Very few other independent variables that affect employee performance that is equal to 0.162 or $16.2 \%$.

The influence of work motivation on employee performance of 0.482 means that tested work motivation affects employee performance. The effect of job satisfaction on employee performance of 0.342 means that job satisfaction is proven to affect employee performance. The influence of organizational climate on employee performance of 0.192 means that organizational climate is proven to affect employee performance. The results of this test found that work motivation has a dominant effect on employee performance.

\section{DISCUSSION}

Employee work motivation was built by the need for power, the need for achievement, and the need for affiliation. The results of research on employee work motivation have been found that employee motivation was formed by the needs of affiliations which are reflected in that employees prefer jobs that require interaction with coworkers. The success of an employee's work is determined by the need to expand relationships. As stated by Robbins (2013) that motivation is a willingness to carry out work with high efforts to achieve organizational goals.

This study measures job satisfaction formed by extrinsic factors and intrinsic factors. The test results show that employee job satisfaction is built by intrinsic factors that are reflected that employees are satisfied with their work that is recognized by the leadership. This means that employees feel they are not doing work in vain. This is related to the statement of Luthans (2012) regarding employee job satisfaction. Luthans (2012) has explained that employee satisfaction is related to the emotional factors that exist in each individual employee.

Organizational climate is measured by structure, standards, responsibilities, recognition, support, and commitment. The results of the study indicate that the organizational climate is more primarily shaped by the structure that is reflected that each employee is responsible for work. Employee performance is formed by hard skills and soft skills. The main thing that can improve employee performance is that hard skills are reflected in work results that are in line with the main tasks and functions. Performance is a potential that must be possessed by every employee to carry out every employee's duties and responsibilities

The relationship between work motivation and employee performance shows that work motivation in which employees want interaction between coworkers has a positive impact on their performance. Employees prefer to work in groups rather than working alone. They assume that working in cooperation accelerates the work process. But for work responsibilities remains the responsibility of individuals. This illustration shows that the Investment and Integrated Services Office of Pasuruan Regency has the character of employees who like to work in cooperation. The success of vision and mission in an institution is determined by the work motivation of employees.

The age of employees in the Investment and Integrated Services Office of Pasuruan Regency is mostly in the range of $31-40$ years $(36 \%)$. This age range dominates the research location office. Age in this range is classified as a period of growth in work so it needs to be improved and given new challenges. But they prefer to work in groups so that leaders need new work innovations so that employees more easily improve their performance.

Robbin's theory (2011) that explains motivation is a willingness to carry out tasks through various efforts still relevant to real conditions in the Investment and Integrated Services Office of Pasuruan Regency, employees at this location want to work collectively. The results of this study support the results of previous studies such as those conducted by Sitorus and Bachri (2014), Sukarman (2014), Rahmawati and Supartha (2015) Rachmawati and Gilang (2017) proving that work motivation influences individual performance. More than a few employees in the Investment and Integrated Services Office of Pasuruan Regency have been working for more than 10 years, with undergraduate education. This means that employees have mastered various types of work. They are already familiar with the leadership characteristics, internal and external environmental conditions of the organization. The results showed that employees were satisfied at work if the results of their work were responded positively by their leaders. Employees want a positive vertical relationship interaction. The results of testing job satisfaction and performance showed a positive effect. The satisfaction of the leadership's concern for the work of employees becomes the basis for thinking employees to do future work better. The results of employee jobs that are responded positively by the leadership make employees feel satisfied and full of enthusiasm, and active in providing services compared to employees who do not get job satisfaction.

The opinion of Kreitner and Kinicki (2010) about job satisfaction in terms of the emotional side of employees is proven in the results of this study. Job satisfaction is part of individual emotions to work better. The results of this study are in line with studies conducted by Dimyati (2011) and Sukarman (2014) which prove that there is an influence of job satisfaction on individual performance. 
The relationship between organizational climate and employee performance in the Investment and Integrated Services Office of Pasuruan Regency shows that organizational climate influences employee performance. The organizational climate in this study was measured by structure, responsibility, appreciation, support, and commitment. Organizational climate is formed by support and commitment has an impact on organizational performance. Support and commitment are needed by employees in work activities. They expect a sense of security at work if the leadership supports a conducive work environment. The results of this study confirm that the organizational climate is a factor that should not be ignored, it needs to be improved continuously in an effort to improve employee performance. The findings of this study are not different from the results of research Rahmawati and Supartha (2015), Yusuf (2017), Pasaribu and Indrawati (2016), Dewi (2017) who have proven that organizational climate is closely related to individual performance in various situations.

\section{CONCLUSION}

Employee motivation in the Investment and Integrated Services Office of the Pasuruan Regency is formed by the need to affiliate with colleagues to complete work. Employee satisfaction is still based on a sense of emotion. Employees are satisfied if the results of their work get a positive response from the leadership of the organization. Employees want a harmonious vertical relationship and a feeling of security at work. The organizational climate at the Investment and Integrated Services Office of the Pasuruan Regency is formed by organizational support and commitment. Office employees want a conducive office environment so that they are comfortable in their work. Work motivation, employee job satisfaction and organizational climate affect employee performance in the Investment and Integrated Services Office of Pasuruan Regency. An important finding of this study is that employee motivation based on collaboration with coworkers can improve employee hard skill performance, that is, the ability gained from work experience.

\section{SUGGESTION}

The conclusions of this study indicate that cooperation is the keyword for organizations in the Investment and Integrated Services Office. To achieve the Vision, Mission, goals, and objectives of the organization needed aspects of cooperation. Most of the employees studied wanted cooperation at work. Therefore, the vertical relationship between subordinates and superiors needs to be strengthened by carrying out better leadership patterns. Basically, office employees want a sense of security, fair and transparent. The recommended pattern of leadership is servant leadership, where the leader is closer to subordinates to serve the community. Research gap for future researchers who wish to carry out a more in-depth investigation of employee work motivation in government offices, especially in the Investment and Integrated Services Office of Pasuruan Regency, which describes what kind of collaboration between colleagues is like. It is recommended to use a qualitative research method to explore cooperation variables.

\section{References}

Dewi, Ekawati Nugraha. 2017. The Effect of Organizational Climate and Employee Competence on Employee Performance in Achieving Quality in Health Services. Jurnal Publik. Vol. 11. No. 01: 89-100.

Dimyati, Muhammad Reza. 2011. Analysis of the Effect of Organizational Culture and Job Satisfaction on Employee Performance with Organizational Commitment as a Mediating Variable. Jurnal Bisnis Strategi. Vol. 20. No.2: 87-106.

Hasibuan, Malayu S.P. 2011. Human Resource Management. Revision edition. Jakarta: Bumi Aksara.

Kreitner, Robert, and Kinicki. 2010. Organizational Behavior. 8th Edition. Boston: McGraw-Hill.

Luthans, Fred. 2012. Organizational Behavior 10th. Indonesian Edition. Yogyakarta: Penerbit ANDI.

Pasaribu, Evan Karno and Ayu Devi Indrawati. 2016.The Effect of Organizational Climate and Quality of Work Life on the Performance of Bali Province Social Service Employees. E-Jurnal Manajemen Unud, Vol. 5. No.12: 7785-7809.

Rachmawati and Gilang. 2017. Effect of Work Motivation on the Performance of Civil Servants (Case Study in the Department of Manpower and Transmigration, West Java Province). Jurnal Computech \& Bisnis, Vol.11. No 2: 79-86.

Rahmawati, Sarah and Wayan Gede Supartha. 2015. Effect of Organizational Climate and Work Motivation on Employee Job Satisfaction in the Bali River Region - Penida.E-Jurnal Manajemen Unud, Vol. 4. No. 11: 3405-3437.

Rivai, Vethzal, and Basri. 2005. Performance Appraisal: The right system to Assess Employee Performance and Increase Company Competitiveness. Jakarta: PT. Raja Grafindo Persada.

Robbins, Stephen P. 2013. Organizational behavior. Jakarta: PT Indeks Kelompok Gramedia.

Simamora, Henry. 2010. Human Resource Mananagement. Second Edition. Yogyakarta : Aditya Media.

Sitorus, Royen Bertoniand Ahmad Alim Bachri. 2014. The Effect of Work Motivation and Work Discipline on the Performance of Employees of the Communication and Information Office of Katingan Regency.Jurnal 
Wawasan Manajemen, Vol. 2. No.1: 57-79.

Stringer, Robert. 2006. Leadership and Organizational Climate: The Cloud Chamber Effect. Upper Saddle River, NJ: Prentice-Hall

Sukarman. 2014.Effect of Motivation, Organizational Culture and Work Environment on Job Satisfaction and Employee Performance of the Ministry of Manpower and Transmigration, Central Kalimantan Province. KINDAI. Vol. 10 No. 3: 218-236.

Winardi. 2011.Leadership in Management.Jakarta. PT. Rineka Cipta.

Wirawan. 2010. Organizational Culture and Climate. Jakarta. Salemba Empat.

Yusuf, Yusni Hervy. 2017. The Influence of Organizational Climate and Maturity on the Performance of the Banda Aceh City Culture and Tourism Office Staff. Jurnal Manajemen dan Akuntansi, Vol.3. No.2: 40-49. 